\title{
PENERAPAN MODEL PEMBELAJARAN PROBLEM BASED LEARNING UNTUK MENINGKATKAN HASIL BELAJAR MATEMATIKA DAN BERFIKIR KRITIS SISWA KELAS 4 SD
}

\author{
Niken Bekti Utamiax ${ }^{\text {ax }}$ Firosalia Kristin ${ }^{b}$, Indri Anugraheni ${ }^{\mathrm{c}}$ \\ a,b,c PGSD FKIP Universitas Kristen Satya Wacana, Jl. Diponegoro 52 - 60 Salatiga \\ ${ }^{x}$ Corresponding author: $292015020 @$ student.uksw.edu
}

\begin{abstract}
.
This study aims to improve critical thinking skills and student learning outcomes through the application of Problem Based Learning (PBL) learning models in Grade 4 Mathematics learning. This type of research is Classroom Action Research (CAR) with two cycles. The subjects of this study were 4th grade students of SDN Randuacir 02, amounting to 25 students. Data collection techniques are carried out using tests in the form of questions and non-tests in the form of rubrics. This study uses qualitative and quantitative descriptive data analysis techniques. The results of this study indicate that there is an increase in critical thinking skills and learning outcomes of 4th grade students of SDN Randuacir 02 through application using the Problem Based Learning (PBL) learning model. This is evidenced by the increase in students' critical thinking, namely in the first cycle the average value is 58.92. Whereas, in cycle 2 there was an increase in the average value of 80.28. Experiencing an increase in the completeness of students' mathematics learning outcomes in the pre-cycle stage as many as 7 students with an average value of 55.00, then increasing in the first cycle as many as 10 students with the average score of 63.52 and increasing again in cycle 2 to 22 students with an average score of 82.00
\end{abstract}

\section{Keywords: Problem Based Learning, Critical Thinking, Learning Outcomes, Mathematics}

\begin{abstract}
Abstrak.
Penelitian ini bertujuan untuk meningkatkan kemampuan berfikir kritis dan hasil belajar siswa melalui penerapan model pembelajaran Problem Based Learning (PBL) pada pembelajaran Matematika kelas 4. Jenis penelitian ini adalah Penelitian Tindakan Kelas (PTK) dengan dua siklus. Subjek penelitian ini adalah siswa kelas 4 SDN Randuacir 02 yang berjumlah 25 siswa. Teknik pengumpulan data dilakukan dengan menggunakan tes dalam bentuk soal dan non tes berupa rubrik. Penelitian ini menggunakan teknik analisis data deskriftif kualitatif dan kuantitatif. Hasil penelitian ini menunjukkan bahwa ada peningkatan dalam kemampuan berfikir kritis dan hasil belajar siswa kelas 4 SDN Randuacir 02 melalui penenerapan model pembelajaran Problem Based Learning (PBL). Hal ini dibuktikan dengan peningkatan berfikir kritis siswa yaitu pada siklus I nilai rata-rata sebesar 58,92. Pada siklus 2 mengalami peningkatan nilai rata-rata sebesar 80,28. Pada hasil belajar siswa juga terjadi peningkatan hal tersebut ditujukan dari ketuntasan belajar siswa pada tahap pra siklus sebanyak 7 siswa dengan nilai rata-rata sebesar 55,00. Kemudian meningkat di siklus I sebanyak 10 siswa dengan nili rata-rata sebesar 63,52 dan meningkat lagi pada siklus 2 menjadi 22 siswa dengan nilai rata-rata sebesar 82,00.
\end{abstract}

Kata kunci: Problem Based Learning, Berfikir Kritis, Hasil Belajar, Matematika

\section{PENDAHULUAN}

Pendidikan sangat berperan penting dalam maju mundurnya suatu negara. Masa depan bangsa sangat bergantung pada kualitas pendidikan masa kini, dan pendidikan berkualitas akan muncul ketika pendidikan di sekolah juga berkualitas. Arti dari pendidikan itu sendiri, dalam UU Sistem Pendidikan Nasional Nomor 20 Tahun 2013, mengemukakan bahwa. Pendidikan adalah usaha sadar dan terencana untuk mewujudkan suasana belajar dan proses belajar mengajar agar siswa secara aktif mengembangkan potensi dirinya, masyarakat, bangsa, dan Negara. Pendidikan bukan sekedar memberikan pengalaman pengetahuan atau nilai-nilai atau melatihkan keterampilan tetapi mengembangkan apa yang secara potensial dan aktual telah dimiliki siswa. Selain itu guru harus menyediakan ruangan dan fasilititas untuk menunjang pembelajaran dikelas agar berjalan dengan maksimal.

Konsep pembelajaran menurut Corey (Syaiful Sagala, 2011: 61) adalah suatu proses dimana lingkungan seseorang secara 
disengaja dikelola untuk memungkinkan ia turut serta dalam tingkah laku tertentu dalam kondisi-kondisi khusus atau menghasilkan respons terhadap situasi tertentu, pembelajaran merupakan subset khusus dari pendidikan. Kesiapan guru untuk mengenal karakteristik siswa dalam pembelajaran merupakan modal utama penyampaian bahan belajar dan menjadi indikator suksesnya pelaksanaan pembelajaran. Dapat ditarik kesimpulan bahwa. Pembelajaran adalah usaha sadar dari guru untuk membuat siswa belajar, yaitu terjadinya perubahan tingkah laku pada diri siswa yang belajar, dimana perubahan itu dengan didapatkannya kemampuan baru yang berlaku dalam waktu yang relative lama dan karena adanya usaha.

Matematika merupakan salah satu mata pelajaran yang memiliki peran penting dalam mencapai tujuan pendidikan, karena Matematika adalah mata pelajaran yang membekali siswa untuk berfikir logis analitis, sistematis, kritis dan kreatif. Selain itu juga, dengan pembelajaran matematika dapat memberikan tekanan penataran nalar dalam penerapan matematika. Secara khusus, tujuan pembelajaran Peningkatan Aktivita Belajar Matematika Melalui Pendekatan Problem Based Learning Bagi Siswa kelas 4 SD (Normala Rahmadani N., Indri Anugrahenu). Oleh karena itu penguasaan terhadap matematika mutlak diperlukan dan konsep-konsep dalam matematikan merupakan suatu rangkaian sebab akibat. Matematika sekolah terdiri dari bagian-bagian yang dipilih untuk menumbuhkembangkan kemampuankemampuan dan membentuk rasa kepribadian siswa serta berpadu pada perkembangan ilmu pengetahuan dan teknologi. Disamping itu, matematika memberikan kontribusi positif tercapainya masyarakat yang cerdas dan martabat melalui sikap kritis dan berpikir logis (Suminarsih, 2007:1)

Higher Orde of Thinking Skill (HOTS) adalah kemampuan berpikir kritis, logis, reflektif, metakognitif, dan berfikir kreatif yang merupakan kemampuan berfikir tingkat tinggi. Kurikulum 2013 juga menuntut materi pembelajarannya sampai kerucut paling tingkat yang tinngi yang mensyaratkan siswa mampu untuk memprediksi, mendesain, dan memperkirakan. Sejalan dengan itu ranah dari HOTS yaitu analisis yang merupakan kemampuan berfikir dalam difokuskan ke aspek-aspek atau elemen dari sebuah konteks tertentu. Untuk dapat melatih kecerdasan berfikir pada siswa, disini akan membahas salah satu diantaranya yaitu dengan cara berfikir kritis. Berpikir kritis merupakan proses berpikir intelektual di mana pemikir dengan sengaja menilai kualitas pemikirannya, pemikir menggunakan pemikiran yang reflektif, independen, jernih, dan rasional. Proses tersebut dilalui setelah menentukan tujuan, mempertimbangkan, dan mengacu langsung kepada sasaran-merupakan bentuk berpikir yang perlu dikembangkan dalam rangka memecahkan masalah, merumuskan kesimpulan, mengumpulkan berbagai kemungkinan, dan membuat keputusan ketika menggunakan semua keterampilan tersebut secara efektif dalam konteks dan tipe yang tepat.

Berdasarkan hasil pengamatan pada kelas 4 di SD Negeri Randuacir 02 Salatiga yaitu diperoleh data bahwa, dalam pembelajaran matematika banyak siswa yang belum mencapai Kriteria Ketuntasan Minimal KKM yang telah ditetapkan yaitu 70 terbukti dari nila rata-rata kelas yang hanya mencapai 65 , sementara dilihat dari ketuntasan individu berdasarkan KKM , diperoleh dari 25 siswa hanya 6 orang siswa (42\%) yang telah mendapat nilai Baik, sedangkan 19 orang siswa (58\%) perlu bimbingan atau belum mencapai KKM. Sedangkan hasil observasi kegiatan berfikir siswa pada saat dipertemuan awal sebelum melakukan tindakan per siklus dengan rata-rata sebesar 45,47. Berdasarkan hasil observasi yang dilakukan oleh peneliti masih banyak siswa yang belum memiliki kemampuan berpikir kritis. Hal ini dikarenakan sifat siswa yang masih ingin bermain dan cenderung belum peduli dengan apa yang dilakukan. Kebanyakan siswa masih senang bermain-main, tidak peka terhadap permasalahan di sekitarnya, daya keingintahuannya sangat rendah, motivasi belajar yang masih rendah, tidak memperhatikan ketika guru memberikan pelajaran di kelas, dan lain sebagainya.

Hasil analisis yang dilakukan oleh 
peneliti berpikir kritis sangat sulit ditanamkan kepada siswa. Kemampuan berpikir kritis siswa dapat diamati dari aktivitas yang dilakukan sehari-hari di sekolah ataupun di luar sekolah, meliputi: diskusi, bertanya, menjawab pertanyaan, mengemukakan pendapat, mempertimbangkan sebuah solusi dari suatu permasalahan, interaksi dengan orang lain dan lain sebagainya. Menurtu data berfikir kritis di SD tersebut kurangnya kemampuan siswa terhadap memecahkan soal cerita matematika, mengakibatkan kualitas pembelajaran matematika masih rendah sampai saat ini. Salah satu materi yang menekankan penyelesaian masalah adalah cara menyelesaikan soal cerita materi perbandingan. Banyak faktor penyebab rendahnya hasil belajar siswa pada pemecahan soal cerita. Salah satu faktor yaitu proses pembelajaran dikelas. Selama ini ada kecenderungan bahwa guru tidak melibatkan siswa secara aktif dalam proses pembelajaran, sehingga untuk mengatasi persoalan di atas perlu diusahakan menggunakan model pembelajaran Problem Based Learning agar hasil belajar siswa menjadi optimal.

Penelitian Tindakan Kelas (PTK) ini dilakukan sesuai latar belakang yang telah dijelaskan diatas, dengan bertujuan untuk mendiskripsikan langkah-langkah Problem Based Learning, dan meningkatakan cara berfikir kritis siswa menggunakan model pembelajaran Problem Based Learning. Selain, itu model pembelajaran Problem Based Learning juga dapat meningkat hasil belajara siswa berbantuan media gambar yang berisi permasalahan pada pembelajaran matematika dengan materi Bangun Datar kelas 4 SD Negeri Randuacir 02 .

\section{KAJIAN PUSTAKA}

Menurut Anugraheni (2018:11) Model pembelajaran Problem Based Learning (PBL) dalam model pembelajaran berbasis masalah merupakan suatu model pembelajaran yang melibatkan siswa dalam kegiatan pembelajaran dan mengutamakan permasalahan nyata baik dilingkungan rumah, sekolah, serta masyarakat sebagai dasar untuk memperoleh pengetahuan dan konsep melalui kemampuan keterampilan dalam berpikir kritis dan memecahkan masalah. Pembelajaran Problem Based Learning mengharuskan siswa bekerja dalam tim untuk memecahkan masalah dunia nyata. Pembelajaran menggunakan model Problem Based Learning akan menghasilkan pembelajaran bermakna bagi siswa. Problem Based Learning membuat siswa belajar memecahkan suatu masalah sehingga siswa akan menerapkan pengetahuan yang dimilikinya atau berusaha mengetahui pengetahuan baru yang diperlukan untuk memecahkan masalah tersebut. Belajar dapat semakin bermakna dan dapat diperluas ketika siswa berhadapan dengan situasi di mana konsep diterapkan. Problem Based Learning dapat juga menumbuhkan inisiatif siswa dalam bekerja, motivasi internal untuk belajar, dan dapat mengembangkan hubungan interpersonal dalam bekerja individu.

Menurut dari beberapa model, salah satu model pembelajaran yang berorientasi pada hal tersebut adalah dengan menerapkan model pembelajaran Problem Based Learning. Model pembelajaran berbasis masalah ini bertujuan untuk mengajarkan proses berfikir tingkat tinggi, membantu siswa memproses informasi yang telah dimilikinya, dan membangun sendiri pengetahuannya tentang apa yang telah diajarkan kepadanya.

\section{METODE PENELITIAN}

Jenis penelitian yang digunakan dalam penelitian ini adalah Penelitian Tindakan Kelas. Penelitian ini dilaksanakan pada siswa kelas 4 SD Negeri Randuacir 02 Salatiga tahun ajaran 2018/2019 yang berjumlah 25 siswa dengan kemampuan yang berbeda-beda. Dalam perencanaan peneliti terdapat 2 siklus, pada siklus I meliputi kegiatan perencanaan, tindakan, observasi dan refleksi, dilanjutkan pada siklus 2 dengan rangkaian kegiatan revisi siklus I, perencanaan, tindakan, observasi, dan refleksi.

Pengumpulan data yang digunakan dalam pelakasanaan pembelajaran matematika dengan teknik observasi, rubrik dan tes. Lembar observasi yang digunakan berupa rubrik berfikir kritis dengan berisikan indikator penilaian yang digunakan untuk mengukur kemampuan berfikir kritias siswa dengan melakukan 
observasi kegiatan siswa pada saat proses pembelajaran berlangsung. Sedangkan, tes berupa soal memuat indikator pembelajaran bertujuan sebagai alat ukur peningkatan hasil belajar siswa dengan berbentuk soal pilihan ganda. Penjabaran penelitian berupa data yang berkaitan dengan permasalahan dan tujuan dari penelitian diuraikan dengan teknik analisis data deskriptif kualitatif. Teknik analisis data menggunakan analisis deskriptif kuantitatif. Pengukuran yang dilaksanakan pada siswa dikategorikan dengan kriteria yang telah ditentukan terlebih dahulu. Keberhasilan yang dicapai tergantung pada penguasaan materi atas kriteria yang telah dijabarkan dalam indikator pertanyaan guna mendukung tujuan tersebut.

\section{HASIL DAN PEMBAHASAN}

Data hasil rubrik berfikir kritis dan hasil belajar siswa yang didapatkan setelah melakukan penelitian pada siklus I dan siklus 2 sesuai dengan menggunakan model pembelajaran Problem Based Learning berbantuan media gambar berikan permasalahan materi matematika kelas 4 SD Negeri Randuacir 02 Salatiga.

Perbandingan hasil kegiatan berfikir kritis siswa berdasarkan tabel 1 dapat dilihat yang menunjukkan hasil yaitu terjadi peningkatan pada tahap pra siklus ke siklus I ke siklus 2 terhadap hasil kegiatan berfikir kritis siswa pada saat proses pembelajaran dengan penerapan model pembelajaran Problem Based Learning. Hasil data yang diperoleh melalui hasil observasi pada proes pembelajaran dan dengan menghitung seluruh indikator kegiatan berfikir kritis siswa. Dapat diketahui dengan menerapkan model pembelajaran Problem Based Learning dapat meningkat hasil kegiatan berfikir siswa pada setiap siklusnya, hal ini dibuktikan dengan perolehan presentase dalam setiap aspek berfikir kritis yang mengalami peningkatan yang signifikan. Presentase hasil kegiatan berfikir kritis siswa dalam kategori sangat baik dan baik yang terjadi pada pra siklus $0 \%$ dan $4 \%$

Berdasarkan tabel 2 tersebut menjelaskan bahwa adanya peningkatan meningkat pada siklus I menjadi $12 \%$ dan $32 \%$ serta pada tindakan siklus 2 meningkat menjadi $76 \%$ dan $12 \%$. Skor rata - rata yang didapat pra siklus 45,67 , kemudian setelah melakukan tindakan siklus I meningkat menjadi 58,92 dan pada tindakan siklus 2 meningkat menjadi 80,28. Setelah dilakukannya tindakan siklus 2 menunjukkan hasil kegiatan berfikir kritis siswa mencapai harapan yaitu $80 \%$ dari jumlah keseluruhan siswa dengan memperoleh skor rata-rata 80,28 memiliki kriteria yang sangat baik. Tabel kegiatan tersebut mengahasilkan data pelaksanaan siklus I dan siklus 2 sebagai berikut :

Tabel 1. Distribusi Frekuensi Perbandingan Dalam Berfikir Kritis

\begin{tabular}{ccccccc}
\hline \multirow{2}{*}{ Kriteria } & \multicolumn{2}{c}{ Pra siklus } & \multicolumn{2}{c}{ Siklus I } & \multicolumn{2}{c}{ Siklus II } \\
\cline { 2 - 7 } & $\mathrm{f}$ & $(\%)$ & $\mathrm{f}$ & $(\%)$ & $\mathrm{f}$ & $(\%)$ \\
\hline Kurang & 10 & 40 & 3 & 12 & 1 & 4 \\
\hline Cukup & 11 & 44 & 11 & 44 & 2 & 8 \\
\hline Baik & 4 & 16 & 8 & 32 & 3 & 12 \\
\hline $\begin{array}{c}\text { Sangat } \\
\text { Baik }\end{array}$ & 0 & 0 & 3 & 12 & 19 & 76 \\
\hline Jumlah & 25 & 100 & 25 & 100 & 25 & 100 \\
\hline $\begin{array}{c}\text { Rata }- \\
\text { rata }\end{array}$ & 45,47 & 58,92 & \multicolumn{2}{c}{80,28} \\
\hline $\begin{array}{c}\text { Kriteia } \\
\text { Cukup }\end{array}$ & Cukup & $\begin{array}{c}\text { Sangat } \\
\text { Baik }\end{array}$ \\
\hline
\end{tabular}

Tabel 2. Distribusi Frekuensi

Perbandingan Ketuntasan Hasil Belajar Matematika Siswa Pra Siklus, Siklus I, dan Siklus 2

\begin{tabular}{|c|c|c|c|c|c|c|c|}
\hline \multirow[t]{2}{*}{ Kriteria } & \multirow{2}{*}{$\begin{array}{c}\text { Nil } \\
\text { ai }\end{array}$} & \multicolumn{2}{|c|}{$\begin{array}{c}\text { Pra } \\
\text { Siklus }\end{array}$} & \multicolumn{2}{|c|}{ Siklus I } & \multicolumn{2}{|c|}{ Siklus 2} \\
\hline & & f & $\%$ & $\mathbf{f}$ & (\%) & $\mathbf{f}$ & (\%) \\
\hline Tuntas & $\geq 70$ & 7 & 28 & 10 & 40 & 22 & 88 \\
\hline $\begin{array}{l}\text { Tidak } \\
\text { Tuntas }\end{array}$ & $<70$ & 18 & 72 & 15 & 60 & 3 & 12 \\
\hline Jumlah & & 25 & 100 & 25 & 100 & 25 & 100 \\
\hline Rata & & & & & & & \\
\hline
\end{tabular}

yang terjadi pada setiap siklusnya, hal tersebut ditunjukan dengan adanya 
perbandingan dari prasiklus, siklus I juga siklus II. Ketuntasan pada prasiklus sejumlah 7 siswa dan mengalami peningkatan di siklus I menjadi 10 siswa dan peningkatan terjadi kembali disiklus II menjadi 22 peserta didik. Kemudian ketidaktuntasan terjadi dari prasiklus yang berjumlah 18 peserta didik berkurang di siklus I menjadi 15 peserta didik dan berkurang kembali pada siklus II menjadi 3 peserta didik. Dari penjelasan tersebut dapat dikaji bahwa menerapkan Problem Based Learning bisa mempengaruhi peningkatan hasil belajar siswa, karena adanya pada hasil siswa yang mengalami peningkatan. Hal tersebut memperkuat penelitian sebelum-nya yang dilakukan Ardiansyah (2017;2) yang dalam pelaksanaan penelitiannya model pembelajaran Problem Based Learning dapat digunakan untuk membuat peningkatan hasil belajar peserta didik SD terutama untuk penerapan materi pelajaran matematika.

Berdasarkan perolehan hasil belajar dan berfikir kritis siswa dengan menerapkan model pembelajaran Problem Based Learning yang didapat dalam siklus I dan siklus 2 bahwa dapat disimpulkan terjadi peningkatan pada materi bangun datar dipelajaran matematika kelas 4 SD Negeri Randuacir 02 Salatiga. Hasil penelitian ini sejalan dengan pendapat Kristin (2017:223) bahwa hasil belajar adalah merupakan perubahan perilaku siswa setelah mengikuti pelajaran terjadi akibat lingkungan belajar yang sengaja dibuat oleh guru melalui model pembelajaran yang dipilih dan digunakan dalam suatu pembelajaran. Selain itu hasil penelitian ini telah melengkapi dan memperkuat penelitian terdahulu seperti penelitian yang telah dilakukan oleh Normala Rahmadani (2017) dimana dengan penerapan model Problem Based Learning (PBL) dapat untuk meningkatkan berfikir kritis iswa. Problem based learning juga digunakan oleh Riana Rahmasari (2016) dalam penelitiannya membuktikan bahwa Problem Based Learning (PBL) dapat untuk meningkatkan pembelajaran. Berdasarkan penelitian diatas membuktikan bahwa model pembelajaran Problem Based Learning dapat meningkatkan kualitas pembelajaran. Hal yang membedakan penelitian ini dengan penelitian sebelumnya yaitu penelitian ini bertujuan untuk meningkatkan cara berfikir kritis dan hasil belajar siswa pada kelas 4 SD. Karena dalam proses belajar mengajar, siswa dapat diartikan bisa dituntut untuk berfikir secara kritis agar dapat mencari atau menemukan jawaban sendiri tentang permasalahannya sehingga memacu siswa untuk berpikir kritis.

Keunggulan dalam penelitian ini dibandingkan dengan penelitian lainnya, yaitu dalam penelitian ini penerapan model pembelajaran Problem Based Learning (PBL) dengan mengukur berfikir kritis siswa dan hasil belajar siswa. Pengukuran kemampuan berfikir kritis ini menggunakan rubrik berfikir kritis yang dihitung dari rata-rata nilai dengan menerapkan teori Sudjaja (2011:7). Hasil belajar siswa diukur dengan menggunakan soal cerita yang berbentuk pilihan ganda yang dihitung untuk pencapaian nilai diatas KKM pada siswa. Setelah diterapkanya model pembelajaran Problem Based Learning kemampuan berpikir kritis peserta didik mengalami peningkatan, ditunjukan dengan banyaknya siswa yang kritis dalam mengikuti pembelajaran. Kenaikan kemampuan berpikir kritis berimbas kepada hasil belajar pada peserta didik yang mengalami kenaikan, ditunjukan oleh meningkatnya jumlah peserta didik yang mencapai nilai KKM. Selain itu pada proses kegiatan peserta didik mengikuti pembelajaran sesuai model Problem Based Learning sehingga peserta didik dapat menentukan mengemukakan mengumpulkan menyimpulkan permasalahan hipotesis awal,
data dan dapat masalah yang termuat dalam kegiatan pembelajaran.

\section{KESIMPULAN DAN SARAN}

a. Kesimpulan

Berdasarkan dengan hasil penelitian dan pembahasan, maka dapat disimpulkan bahwa dengan menggunakan model Problem Based Learning dan kemampuan berfikir kritis siswa dapat meningkatkan hasil belajar matematika materi bangun datar pada siswa kelas 4 SD $\mathrm{N}$ Randuacir 02 Argomulyo semester 2 
Tahun Pelajaran 2018/2019. Hal ini dapat ditunjukkan dengan perolehan rubrik kemampuan berfikir kritis pada tindakan siklus I terjadi dengan ratarata 58,92 sedangkan pada tindakan di siklus II ada peningkatan dengan jumlah rata-rata yaitu 80,28. Sedangkan pada nilai hasil belajar matematika siswa diketahui dari 25 siswa yang tuntas sebelum melakukan tindakan yaitu 7 siswa dengan persentase $28 \%$. Setelah melakukan tindakan pada siklus I terjadi peningkatan dengan jumlah ketuntasan menjadi 10 siswa dengan persentase $40 \%$, kemudian setelah dilakukan tindakan pada siklus II terjadi peningkatan dengan jumlah ketuntasan yaitu 22 siswa dengan persentase $88 \%$. Penggunaan dengan model Problem Bsed Learning dan kemampuan berfikir siswa dapat meningkatkan hasil belajar siswa siswa kelas 4 SD N Randuacir 02 Argomulyo, Salatiga. Hal ini terjadi karena beberapa langkah-langkah penggunaan model Problem Based Learning sudah terlaksana dengan baik seperti; (1) orientasi siswa pada masalah yang akan dipecahkan ; (2) siswa berkelompok/ individu untuk menerima masalah; (3) siswa melaksanakan investigasi; (4) siswa menganalisis data; (5) siswa membuat laporan;

b. Saran

Bagi peneliti adalah diharapkan kepada guru bahwa model pembelajaran Problem Based Learning (PBL) dapat dijadikan salah satu pilihan yang dapat dipergunakan oleh guru dalam pembelajaran. Pembelajaran dengan menggunakan model Problem Based Learning (PBL) sebaiknya dipilih materi yang dapat dikaitkan dengan kejadian nyata disekitar siswa sehingga siswa lebih tertarik dalam menyelesaikan permasalahan tersebut. Model pembelajaran Problem Based Learning (PBL) terus dikembangkan dalam pembelajaran karena sangat membantu anak untuk melatih pemecahan masalah yang dihadapinya, model Problem Based Learning (PBL) sangat tepat diterapkan pada siswa kelas atas untuk membantu berpikir tingkat tinggi. Serta diharapkan untuk penggunaan model pembelajaran Problem Based Learning (PBL) bisa terus digunakan dalam proses pembelajaran di kelas pada materi pokok. Bagi penelitian selanjutnya, diharapkan bisa menerapkan model Problem Based Learning untuk kelas lainnya atau yang lebih tinggi. Dan dapat digunakan pada muatan pelajaran yang lainnya.

\section{DAFTAR PUSTAKA}

Abdullah, In Hi. "Berpikir kritis matematik." Delta-Pi: Jurnal Matematika dan Pendidikan Matematika 2.1 (2016).

Anugraheni, I. (2018). Meta Analisis Model Pembelajaran Problem Based Learning dalam Meningkatkan Keterampilan Berpikir Kritis di Sekolah Dasar [A Meta-analysis of Problem-Based Learning Models in Increasing Critical Thinking Skills in Elementary Schools]. Polyglot: Jurnal Ilmiah, 14(1), 9-18.

Agustin, Vivin Nurul. "Peningkatan Aktivitas dan Hasil Belajar Siswa Melalui Model Problem Based Learning (PBL)." Journal of Elementary Education 2.1 (2013).

Amir, Mohammad Faizal. "Proses berpikir kritis siswa sekolah dasar dalam memecahkan masalah berbentuk soal cerita matematika berdasarkan gaya belajar." JURNAL

MATH EDUCATOR NUSANTARA: Wahana Publikasi Karya Tulis Ilmiah di Bidang Pendidikan Matematika 1.2 (2015).

Arikunto, S.Dkk. 2006. Penelitian Tindakan Kelas. Jakarta: Bumi Aksara.

Ariyanto, Metta, Firosalia Kristin, And Indri Anugraheni. "Penerapan Model Pembelajaran Problem Solving Untuk Meningkatkan Kemampuan Berpikir Kritis Dan Hasil Belajar Siswa." Jgk 
(Jurnal Guru Kita) 2.3 (2018): 106-115

Asriningtyas,

Anastasia

Nandhita. Penerapan Model

Pembelajaran Problem Based

Learning untuk Meningkatkan

Kemampuan Berpikir Kritis dan Hasil

Belajar dalam Menyelesaikan Soal

Cerita pada Mata Pelajaran

Matematika Kelas 4 SD Negeri Suruh

Dimyati, \& Mudijono. (2010). Belajar dan Pembelajaran. Yogyakarta: Pustaka Belajar.

Gunawan, Imam. "Metode penelitian kualitatif." Jakarta: Bumi Aksara (2013).

Hanifah, Hanifah. "Buku Model Apos Inovasi Pada Pembelajaran Matematika."

Karim, Asrul. "Penerapan metode penemuan terbimbing dalam pembelajaran matematika untuk meningkatkan pemahaman konsep dan kemampuan berpikir kritis siswa sekolah dasar." Jurnal Pendidikan 1.1 (2011): 21-32.

Kristin, F. (2016). Analisis Model

Pembelajaran Discovery Learning

Dalam Meningkatkan Hasil

Belajar Siswa Sd. Jurnal

Pendidikan Dasar

Perkhasa, 2(1), 90-98.

Noer, Sri Hastuti. "Kemampuan berpikir kreatif matematis dan pembelajaran matematika berbasis masalah OpenEnded." Jurnal

Pendidikan Matematika 5.1 (2011).

Rahmadani, N., \& Anugraheni, I. (2017). Peningkatan aktivitas belajar matematika melalui pendekatan problem based learning bagi siswa kelas 4 SD. Scholaria: Jurnal Pendidikan Dan Kebudayaan, 7(3), 241-250.

Sugiyono. 2010. Statistika Untuk Penelitian . Bandung: ALVABETA.

Sumartini, Tina Sri. "Peningkatan kemampuan penalaran matematis siswa melalui pembelajaran berbasis
01. Diss. Program Studi Pendidikan Guru Sekolah Dasar FKIP-UKSW, 2018.

Dewi, Sari Kusuma, I. Made Suarjana, and Made Sumantri. "Penerapan model polya untuk meningkatkan hasil belajar dalam memecahkan soal cerita matematika siswa kelas V." MIMBAR PGSD Undiksha 2.1 (2014). masalah." Mosharafa: Jurnal Pendidikan Matematika 4.1 (2015): 110.

Sochibin, A., P. Dwijananti, and P. Marwoto. "Penerapan model pembelajaran inkuiri terpimpin untuk peningkatan pemahaman dan keterampilan berpikir kritis siswa SD." Jurnal Pendidikan Fisika Indonesia 5.2 (2009).

Wardani, N. S., \& Slameto, A. W. (2012). Asesmen Pembelajaran SD. Salatiga: Widya Sari.

Witantri, Meika, Firosalia Kristin, and Indri Anugraheni. "Peningkatan Kemampuan Berpikir Kritis Dan Hasil Belajar Peserta Didik Denganmenerapkan Model Pembelajaran Problem Solving pada Pembelajaran Tematik Tema 4 Kelas 4 Tahun Ajaran 2018/2019." Kalam Cendekia Pgsd Kebumen7.2 (2019). 
40 EduMa Vol. 8 No. 1 Juli 2019

ISSN $2086-3918$ 